
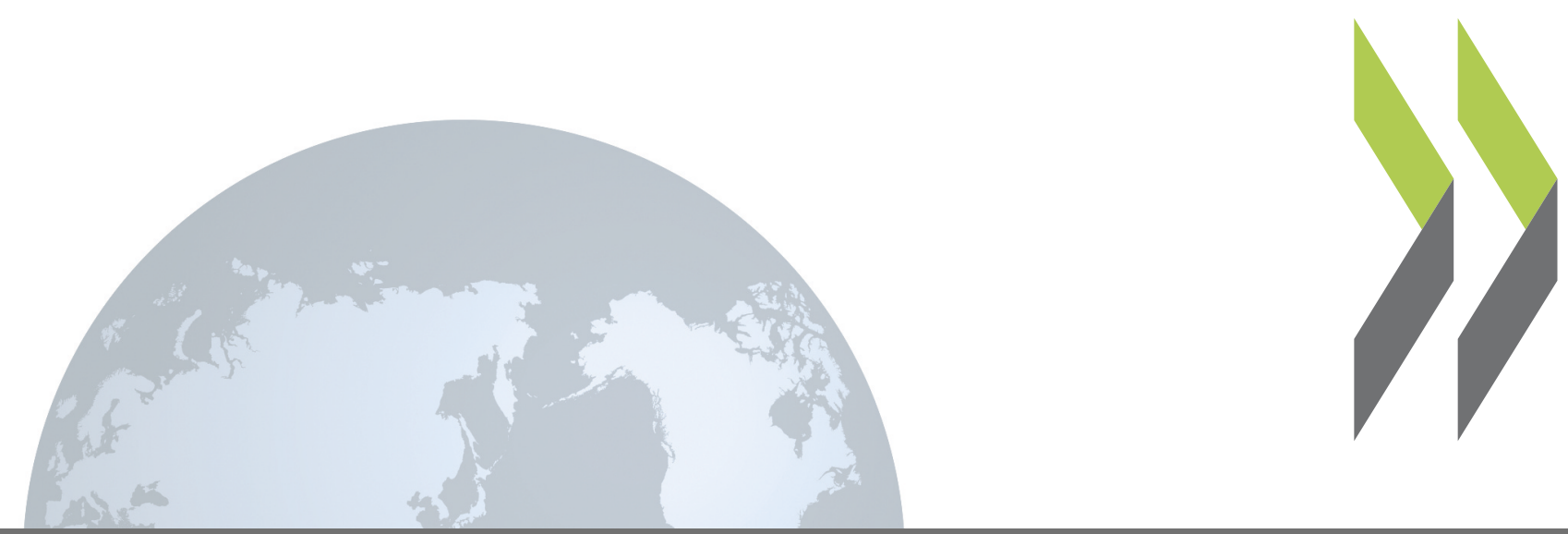

OECD Labour Market and Social Policy Occasional Papers No. 55

\title{
Public Support for Retirement Income Reform
} Peter Hicks 
Organisation de Coopération et de Développement Economiques

Organisation for Economic Co-operation and Development

17-Dec-2001

DIRECTORATE FOR EDUCATION, EMPLOYMENT, LABOUR AND SOCIAL AFFAIRS

English/French EMPLOYMENT, LABOUR AND SOCIAL AFFAIRS COMMITTEE

LABOUR MARKET AND SOCIAL POLICY - OCCASIONAL PAPERS N55

PUBLIC SUPPORT FOR RETIREMENT INCOME REFORM

Peter Hicks

At the time this paper was drafted, Peter Hicks worked in the Social Policy Division of the OECD in Paris, where he co-ordinated work on the policy implications of ageing. He is currently a consultant in Ottawa, Canada, and can be reached at e-mail: prhicks@attglobal.net 


\title{
OCCASIONAL PAPERS
}

This series is designed to make available to a wider readership selected labour market and social policy studies prepared for use within the OECD. Authorship is usually collective, but principal writers are named. The papers are generally available only in their original language -- English or French -- with a summary in the other.

Comment on the series is welcome, and should be sent to the Directorate for Education, Employment, Labour and Social Affairs, 2, rue André-Pascal, 75775 PARIS CEDEX 16, France. Additional, limited copies are available on request.

The opinions expressed and arguments employed here are the responsibility of the author(s) and do not necessarily reflect those of the OECD

\section{Applications for permission to reproduce or translate all or part of this material should be made to:}

\author{
Head of Publications Service \\ OECD \\ 2, rue André-Pascal \\ 75775 Paris, CEDEX 16 \\ France
}

Copyright OECD 2001 
DEELSA/ELSA/WD(2001)8

\section{INTRODUCTION AND SUMMARY}

1. The OECD has undertaken a comparison of the resources of older people in nine OECD countries - Canada, Finland, Germany, Italy, Japan, the Netherlands, Sweden, the United Kingdom and the United States - and has examined how the incomes of older people are influenced, directly and indirectly, by government policies. ${ }^{1}$ The study finds that a new policy agenda is emerging, one that is likely to focus on how policy can support:

- A transition from full-time work to retirement that is later, on average, than at present and that provides greater opportunities for more flexible and gradual pathways to full retirement. There would be a realistic possibility for many people to have a continued attachment to the labour force, and an active life in society, well into later life. However, highest priority would be on encouraging later retirement for those who now retire well before age 65 .

- A diversified system of income support for older people during retirement (and the transition to retirement), with several significant and sustainable elements. This would include a significant role for public and private pensions, for defined-benefit and defined-contribution arrangements, for advance-funded and pay-as-you-go elements. It would include a greater role for earnings and greater coherence of retirement income policies with related financial market, labour market and taxation policies.

- The continued provision of an adequate material standard of living for people in a more diverse system, consistent with a dignified life in retirement and during the transition to retirement. This would include special attention to vulnerable people for whom large private retirement savings, or employment in their older years, may not be a realistic possibility.

2. This background paper uses public attitude data in the nine countries to examine the possible reaction to a policy agenda that was framed in this manner. As with all survey data, international comparisons must be made with caution: answers will reflect linguistic and cultural responses to question phraseology as well as "real" differences. But such caution is no reason to ignore such evidence. For further discussion, see Smith 2001a, 2001b.

3. There are good reasons why people like existing arrangements and why changes to those arrangements, unless handled well, could be treated negatively. Retirement income policies have been quite successful in meeting their income support goals. Most people in most of the studied countries appear to at least maintain their material living standards when they stop working. Reform is needed for familiar reasons related to increasing longevity and the coming retirement of the baby-boom generation. The risk is that, unless care is exercised, reforms could undermine past success and increase the vulnerability of some

1. The resulting publication, with the working title, Ageing and Income: Financial Resources and Retirement in Nine OECD countries, is scheduled for publication in the autumn of 2001. The publication draws on some of the public opinion data found in this working paper. 
groups of older people. Taken in isolation, some reforms, such as those the require people to work longer, can seem to be unpopular, backward steps.

4. Most reform involves later retirement and of a larger role for private pensions. The consequence is, of course, a smaller share of public pension expenditure. While there are social and broader economic gains from moving in this direction, there could well be a cynical reaction if the reform agenda were seen as simply a way of justifying another attempt to cut public pensions. Some have expressed concern about a debate that might cause intergenerational tension. More generally, it would not make sense to launch an exercise to build understanding, engagement and political support using a framework that could polarise the debate.

5. In summary, the evidence examined here suggests that most people in the nine countries do, in fact, favour existing arrangements - whatever they happen to be. That is a realistic view in light of the success of those policies. Nevertheless, regardless of personal preferences, most people have little confidence that existing arrangements will continue. They expect change. Again this is a realistic reflection of future demographic pressures on the retirement income systems.

6. A lesser public role and a greater private pension role is not welcomed but is anticipated. Opinion is more ambiguous about the prospect of working longer. People look forward to, and are generally happy in, retirement. There is, however, no objection to working later in life in principle. Indeed it would be welcomed if appropriate work were there. The standard of what constitutes suitable work is, however, high and people expect the chances of finding such work are small.

7. There will be more older voters in the future, but the data do not point to any direct consequences for the reform agenda discussed here. Indeed, there appears nothing in public opinion that would suggest that policy debate along these lines need have a polarising effect or be received negatively - provided that those debates were framed sensibly, especially if they encompassed issues surrounding the supply of suitable jobs for older people. 
DEELSA/ELSA/WD(2001)8

\section{INTRODUCTION ET RESUME}

1. L'OCDE a entrepris de comparer les ressources des personnes âgées dans neuf pays de l'OCDE - Allemagne, Canada, Etats-Unis, Finlande, Italie, Japon, Pays-Bas, Royaume-Uni et Suède --, cherchant, en particulier, à voir comment les revenus des personnes âgées subissent, directement ou indirectement, l'incidence des politiques publiques ${ }^{2}$. Cette étude met en évidence l'apparition d'un nouveau défi pour les pouvoirs publics, qui devront s'efforcer d'accompagner certaines évolutions :

- Faire que le passage d'une activité à plein temps à la retraite s'effectue plus tardivement, en moyenne, que ce n'est le cas actuellement, et selon des modalités plus souples et plus graduelles avant d'en arriver à une cessation complète d'activité. Ainsi, de nombreuses personnes pourraient continuer de garder un lien avec le monde du travail et continuer de mener une vie active au sein de la société jusqu'à un âge avancé. Cependant, la première priorité serait d'encourager les personnes qui, actuellement, prennent leur retraite bien avant 65 ans à différer leur départ à la retraite.

- Diversifier les sources de revenu des personnes âgées au moment de la retraite (et durant la phase de transition qui les mènera à la retraite), ce qui suppose de s'appuyer sur plusieurs éléments qui doivent avoir un caractère durable. Plusieurs éléments seraient ainsi appelés à jouer un rôle significatif -- les pensions de régimes publics et les pensions privées, les systèmes à prestations définies et les systèmes à cotisations définies, les mécanismes de la capitalisation et les mécanismes de la répartition. Il faudrait aussi faire une plus large place aux revenus d'activité et renforcer la cohérence des politiques visant le financement de la retraite et des politiques connexes visant le marché financier et le marché du travail, ainsi que de la politique fiscale.

- Continuer d'assurer un niveau de vie matériel satisfaisant aux personnes âgées dans un contexte plus divers, de façon que chacun puisse continuer de mener une vie digne durant la retraite et durant la période d'accès à la retraite. Il faudra être particulièrement attentif à la situation des personnes vulnérables pour qui un gros effort d'épargne, à titre privé, en vue de la retraite, ou la poursuite d'une activité jusqu'à un âge avancé ne sont peut-être pas des options réalistes.

2. L'étude menée par l'OCDE dans neuf pays s'efforce de voir quelle pourrait être la réaction de l'opinion publique à des réformes dans ce sens. Comme avec toutes les enquêtes de données, les comparaisons internationales doivent être effectuées avec prudence : l'analyse des résultats tiendra compte aussi bien des réponses culturelles et linguistiques, de la formulation des questions que des différences «réelles». Cette évidence ne doit toutefois pas être ignorée malgré une telle prudence. Pour plus d'informations sur ce point, voir Smith 2001a, 2001b.

2. La publication qui en résulte, ayant pour titre, Vieillissement et revenus : Les ressources des retraités dans neuf pays de l'OCDE, est prévue d'être publiée en automne 2001. Cet ouvrage se penche sur quelques résultats de sondages d'opinions que l'on peut retrouver dans ce document de travail. 
3. $\quad 11$ est tout à fait compréhensible que les gens soient attachés aux situations existantes et que les tentatives de changement, à moins de faire preuve de beaucoup de doigté, soient perçues négativement. Les politiques visant le financement de la retraite ont fort bien atteint leurs objectifs : la plupart des gens, dans la plupart des pays étudiés, parviennent au moins à maintenir leur niveau de vie matériel lorsqu'ils cessent de travailler. Mais des réformes sont indispensables, pour des raisons bien connues qui tiennent à l'allongement de la durée de la vie et à l'arrivée à l'âge de la retraite de la génération issue du baby-boom. Ce que l'on pourrait craindre, si l'on n'était pas suffisamment attentif à tous les aspects, ce serait de remettre en cause les réussites du passé et d'aggraver la vulnérabilité de certaines catégories de la population âgée. Considérées isolément, certaines réformes, comme celle visant à amener les gens à poursuivre une activité plus longtemps, peuvent être impopulaires, apparaissant comme un retour en arrière.

4. La plupart des réformes impliquent des départs à la retraite plus tardifs et un accroissement du rôle joué par les pensions privées. Cela se traduirait, naturellement, par une certaine réduction de la part des dépenses de pensions publiques. Certes, il y aurait des avantages, sur un plan social et sur un plan économique, à aller dans ce sens, mais cela pourrait susciter de vives réactions si les réformes semblaient ne procéder que de la volonté de réduire les pensions publiques. D'aucuns craignent que le débat ne suscite des tensions entre les générations. De façon plus générale, il faut veiller à ce que les tentatives d'explication, de mobilisation et de ralliement des soutiens ne contribuent pas à créer des clivages dans la société.

5. Les données examinées dans l'étude tendent à montrer que la plupart des gens, dans les neufs pays étudiés, portent, en fait, un jugement favorable sur les dispositifs existants -- quels qu'ils soient. Il y a là un certain réalisme compte tenu de la réussite des politiques qui ont été mises en œuvre. Cela étant, en dépit de leurs préférences personnelles, la plupart des gens ne croient pas que les dispositifs existants puissent perdurer. Ils s'attendent à des changements. Là encore, c'est un point de vue réaliste étant donné les pressions démographiques qui pèseront, à l'avenir, sur les systèmes de retraite.

6. Les gens s'attendent -- même s'ils ne le souhaitent pas -- à ce que le rôle joué par les régimes publics s'amenuise et à ce que les pensions privées jouent, à l'inverse, un rôle accru. Les attitudes sont plus ambiguës vis-à-vis d'un allongement de la durée de la vie active. Les gens se réjouissent à la perspective de partir à la retraite et sont généralement heureux d'être à la retraite. Il n'y a, pour autant, pas d'objection de principe à travailler plus longtemps. Les gens seraient même prêts à s'en réjouir s'ils pouvaient exercer une activité qui leur convienne. Mais ils sont exigeants sur ce qui constitue, à leurs yeux, un emploi convenable, et ils ne s'attendent guère à pouvoir accéder à ce type d'emploi.

7. La population âgée représentera une plus large part de l'électorat à l'avenir, mais les données examinées n'indiquent pas que cela doive peser directement sur les réformes. En fait, rien ne permet de penser qu'une radicalisation des points de vue ou des réactions négatives soient inéluctables, à condition que les enjeux soient correctement posés, sans méconnaître, en particulier, le problème de l'offre d'emplois adaptés aux personnes âgées. 


\section{People support existing arrangements but are not confident they can continue}

8. In most of the countries, public pensions are at the heart of existing arrangements. Table 1 shows that, in 1996, there was wide support for the role of government in providing a decent standard of living for older people ${ }^{3}$. Note, however, that were many "probably" as well as "definitely" responses. Support varies considerably among the seven countries for which data are available. Less than half felt it was "definitely" a responsibility in the United States and Japan. Support was highest in Italy.

9. Support has been falling slightly over time in the four countries for which consistent time series are available as can be seen in Chart 1 .

Table 1 Public views on responsibilities for a decent standard of living for old, 1996

\begin{tabular}{|c|c|c|c|c|c|}
\hline & \multicolumn{5}{|c|}{$\begin{array}{l}\text { Percentage indicating that, on the whole, they think it should, or should not } \\
\text { be, the government's responsibility to provide a decent standard of living for } \\
\text { the old }\end{array}$} \\
\hline & Definitely & Probably & $\begin{array}{c}\text { Probably } \\
\text { not }\end{array}$ & $\begin{array}{c}\text { Definitely } \\
\text { not }\end{array}$ & $\begin{array}{c}\text { Can't } \\
\text { choose }\end{array}$ \\
\hline Canada & 49.1 & 41.5 & 7.0 & 1.7 & 0.8 \\
\hline Germany & 49.9 & 44.5 & 3.1 & 0.4 & 1.8 \\
\hline Italy & 75.6 & 21.7 & 1.8 & 0.3 & 0.7 \\
\hline Japan & 45.2 & 38.3 & 6.1 & 2.3 & 8.1 \\
\hline Sweden & 67.0 & 27.6 & 1.5 & 0.7 & 3.2 \\
\hline United Kingdom & 70.4 & 26.0 & 2.2 & 0.4 & 1.0 \\
\hline United States & 37.9 & 47.6 & 9.8 & 3.3 & 1.5 \\
\hline
\end{tabular}

Source : International Social Survey Programme, 1996.

3. This table, and all tables in the paper that refer to ISSP (International Social Survey Programme) as the source, are drawn from two papers that were prepared for the OECD by Tom W. Smith of the National Opinion Research Centre, University of Chicago. (Smith 2001a and 2001b) 


\section{Chart 1 Percentage indicating that it should definitely be the government's responsibility to provide a decent standard of living for the old}

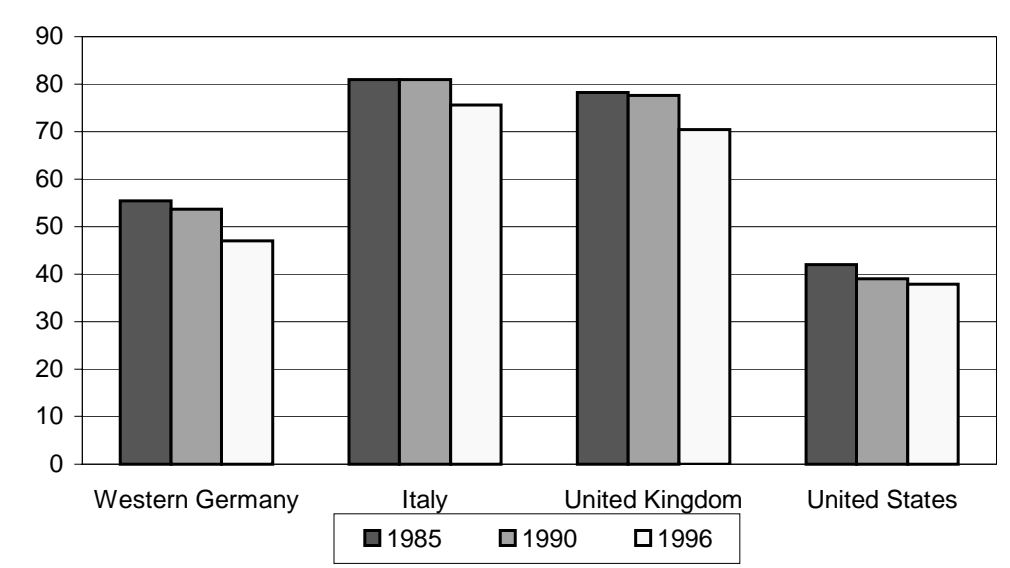

Sources: International Social Survey Programme, 1985, 1990 and 1996.

10. Support is generally higher among women. In terms of labour force status, support is, perhaps unsurprisingly, highest among the retired. Support grows with age, although the gap is not large enough to signal any intergenerational rift. These data are shown in the appended Table A1. The gap between the views of older and younger people does not appear to be strongly related to actual programming arrangements. It was highest in Sweden and Canada, and lowest in the United States and Japan. Nevertheless, the media often reports on intergenerational conflict. The American media, for example, sometimes portray greedy old people being supported by a hard-pressed younger generation, although a review of a large number of American surveys ${ }^{4}$ found that support for Social Security is high among all age groups.

11. The data to this point come from the International Social Survey Programme, which are based on surveys designed to produce internationally comparable data. The tables and analysis here are taken from analysis of that data by Smith (see Footnote 3). A second source of good quality data that allows comparisons across some of the countries in the study, and over time, are the 1992 and 1999 Eurobarometer surveys. The tables shown here (and some of the analytic findings) are taken from an analysis of that data by Walker (1999).

12. These also find a high level of consensus around traditional arrangements. The survey found, for example, that nearly four out of five people agreed with the basic premise of pay-as-you-go pensions, namely that workers have a duty through taxes and contributions to support a decent standard of living among older people.

13. Table 2 shows that most people continue to support both public pensions and employer-based occupational pensions. Support for other private arrangements (such as individual accounts) has grown a little since 1992, but the absolute level remains low - perhaps surprisingly low, given the attention given to the role of privatisation during public debate in the 1990s.

4. Jacobs and Shapiro (1998) 
Table 2 Public views on how pensions should be provided, 1992 and 1999

\begin{tabular}{|c|c|c|c|c|c|c|c|c|}
\hline & \multicolumn{2}{|c|}{ Mainly public } & \multicolumn{2}{|c|}{ Mainly employers } & \multicolumn{2}{|c|}{$\begin{array}{l}\text { Mainly private } \\
\text { arrangements }\end{array}$} & \multicolumn{2}{|c|}{ Don't know } \\
\hline & 1992 & 1999 & 1992 & 1999 & 1992 & 1999 & 1992 & 1999 \\
\hline Finland & .. & 27 & .. & 54 & .. & 9 & .. & 10 \\
\hline Germany & 38 & 40 & 48 & 41 & 7 & 10 & 7 & 10 \\
\hline Italy & 52 & 41 & 24 & 23 & 9 & 18 & 15 & 19 \\
\hline Netherlands & 32 & 37 & 35 & 29 & 20 & 23 & 12 & 11 \\
\hline Sweden & .. & 53 & .. & 23 & .. & 13 & .. & 11 \\
\hline United Kingdom & 48 & 39 & 31 & 31 & 13 & 20 & 8 & 11 \\
\hline
\end{tabular}

.. Data not available.

Source : EUROBAROMETER.

14. While people express support for existing arrangements, they are not confident about the future of those arrangements, at least in the countries in the Eurobarometer survey. The 1992 survey showed that people doubted whether actual public pension arrangements would be able to meet this goal. Table 3 shows that this pessimism has grown since 1992. Most felt that people will get less pension for their contributions in the future and the number who feel this has grown since 1992. Similarly, only a small number of people feel that, taken as a whole, older people will be better off than they are now - at least from public sources. This number has generally fallen since $1992^{5}$.

\section{Table 3 Public views on the future of pensions, 1992 and 1999}

\begin{tabular}{|c|c|c|c|c|}
\hline & \multicolumn{2}{|c|}{$\begin{array}{l}\text { Percentage saying that in the future } \\
\text { people will get less pension for } \\
\text { their contributions }\end{array}$} & \multicolumn{2}{|c|}{$\begin{array}{l}\text { Percentage saying that in the future } \\
\text { the welfare state will continue to } \\
\text { grow and retired people will be } \\
\text { better off than they now are }\end{array}$} \\
\hline & 1992 & 1999 & 1992 & 1999 \\
\hline Germany & 76 & 81 & 25 & 20 \\
\hline Italy & 36 & 57 & 29 & 17 \\
\hline Netherlands & 60 & 64 & 16 & 16 \\
\hline Sweden &.. & 73 &.. & 9 \\
\hline United Kingdom & 50 & 68 & 37 & 16 \\
\hline
\end{tabular}

.. Data not available.

Source : EUROBAROMETER.

5. Walker (1999) reports that there are no large differences in these results by gender or by occupational or income groups. 
15. To some extent, this decline in confidence in the public system is a simple reflection of reality. Pensions and pension promises had become less generous during this period as a consequence of fiscallydriven reforms. For example, countries such as Italy, where reforms have been deepest, show high pessimism (despite a referendum that supported reform). However, closer examination (including that of other European countries that are not part of the nine-country study) shows that there is no obvious relationship between actual reforms and opinions. For example, pension levels are high in the Netherlands and Italy and it may not be surprising that people do not expect that this level of support could be maintained. However, people in the United Kingdom are also pessimistic, despite the fact that pension levels there are relatively low.

16. A 1999 public opinion survey in Canada tells a similar story of preference for traditional arrangements, but a lack of confidence that public benefits can be maintained at present levels ${ }^{6}$, despite recent actions by federal and provincial governments to ensure the sustainability of the arrangements. Most people felt the public earnings-related pension would provide them fewer benefits than those received by retired people today. This was especially so in the age group 25 to 34 , where some 28 per cent expected no public earnings-related pension benefits. Lack of confidence in government management was the largest single reason for concern. Awareness campaigns have been funded to make the effect of the reforms more widely known and to increase understanding of, and confidence in, the retirement income system as a whole.

17. In the United States, there is a low level of confidence in Social Security, and has been since the $1970 \mathrm{~s}^{7}$. However, this does not appear to be weakening basic support for fundamental programme principles, which remains high and little changed.

18. A 1998 survey of experts in social security in $\mathrm{Japan}^{8}$ showed that $70 \%$ wanted to keep the basic two-tier structure. Only 17\% favoured gradual privatisation. However, support for privatisation was higher among younger experts.

\section{Views on a smaller public share and a large share for private pensions}

19. This section turns to views on changes in size of the components of the retirement income system - larger or smaller public and private pensions and earnings.

20. In terms of the size of the public role, Table 4 shows high level of support either for a continuation of public support at its existing levels (Canada) or increased levels (other countries). Another question showed that, while health and education were the most popular targets for more spending, pensions came next - well above law enforcement, unemployment insurance, cultural or military spending.

\footnotetext{
6. Ekos Research Associates, Public Pensions Survey, November 1999.

7. Jacobs and Shapiro (1998).

8. Survey on Pension Reform Plan for Social Security Experts (1998).
} 
Table 4 Public views on more, or less, public retirement spending, 1996

\begin{tabular}{|c|c|c|c|c|c|c|}
\hline & \multicolumn{6}{|c|}{$\begin{array}{l}\text { Percentage indicating that they would like to see more or less government spending on } \\
\text { retirement benefits, } 1996 \\
\text { (with reminder that saying "much more" might require a tax increase to pay for it) }\end{array}$} \\
\hline & Much more & More & Same & Less & Much less & $\begin{array}{l}\text { Can't } \\
\text { choose }\end{array}$ \\
\hline Canada & 6.7 & 20.5 & 61.3 & 8.2 & 1.4 & 1.8 \\
\hline Germany & 13.5 & 32.1 & 47.1 & 3.9 & 0.4 & 2.9 \\
\hline Italy & 17.8 & 48.6 & 23.5 & 4.8 & 2.0 & 3.2 \\
\hline Japan & 25.2 & 30.3 & 33.7 & 2.7 & 1.4 & 6.8 \\
\hline Sweden & 14.6 & 39.4 & 39.5 & 2.3 & 0.1 & 4.1 \\
\hline United Kingdom & 26.5 & 51.1 & 20.9 & 0.8 & 0.3 & 0.4 \\
\hline United States & 12.8 & 36.6 & 38.3 & 7.7 & 2.0 & 2.6 \\
\hline
\end{tabular}

Source: International Social Survey Programme, I, II, III.

21. Support for more public spending for pensions was reasonably stable over the decade from the mid-80s to the mid-90s in the four countries for which the data are available. Germany (West), United Kingdom, Italy and the United States.

22. Support for more spending tends to rise with age in most countries and is highest among the retired. The appended Table A2 shows that Canada and the United States are exceptions, where people of retirement age see less need for increased retirement spending than younger people. This may reflect greater satisfaction of older people with the adequacy of the retirement income systems in those countries even though the public pensions share in those countries is relatively low.

23. It is, however, difficult to interpret these numbers. To some extent they may simply be a realistic reflection of the likely growth in the total amount of spending that will be the consequence of population ageing, and not only preferences about the public spending on a per capita basis. Support for "much more" spending, for example, was high both in the United Kingdom (with a relatively large adequacy challenge) and in Japan (with a relatively large demographic challenge).

24. Do people see a larger share for private pensions? The 1999 Eurobarometer question asked people whether they expected that, in the future, most pensions would be funded by private arrangements with less state involvement. Most people expected to see more private arrangements (ranging from about 60 per cent in Germany and Italy to 80 per cent in Netherlands, Sweden and the United Kingdom). This was not their preference, but their expectation.

25. In the 1999 Canadian survey referred to earlier, most people anticipated that private investments and individual retirement saving accounts would be their main source of income in retirement. Over two thirds of Canadians indicated that they, themselves, were saving for retirement and agreed there was a trend towards individual responsibility. 
26. A 1998 Japanese survey ${ }^{9}$ indicated that $50 \%$ of the people expected to rely on a mix of public and private sources and about $20 \%$ thought they would rely mainly on private savings or pensions

\section{Public views on working longer and early retirement}

27. Do people see a larger share for earnings? Table 5 shows that the number who believe that people who will retire later has grown a little over the 90s in the covered countries and actually fell in Germany. The high Swedish figure is an exception that might reflect the reforms underway there. Data from a different source ${ }^{10}$ suggests that expectations about working longer are lower in Finland than in most European countries. Looking at all the European countries (not only those in the ninecountry study), there seem to be no obvious linkages between actual reforms to raise pensionable ages and the views that are expressed about working longer.

28. In the United States, individualised privatisation has not seen as a solution in the past ${ }^{11}$.

Neither is an increase of the retirement age. Views on other reforms are more mixed, and tend to favour increased contributions rather than reduced benefits.

29. These public views, which see an increased role for private pensions and, perhaps, less so for earnings, mirror well actual trends. There has been a trend towards a somewhat larger role of private pensions and a smaller role for earnings, reflecting past trends towards early retirement. The subsequent stabilisation of early retirement trends in very recent years (which is discussed in the main OECD study) could not, of course, have been clearly seen in 1999.

30. The remainder of this section deals more directly with views on later retirement. In general, retirement is viewed positively. In the Eurobarometer survey, people in the European countries reported that they look forward to retirement ${ }^{12}$. The results are similar regardless of actual differences in national retirement ages.

31. Most people appear to be happy in retirement. In Canada ${ }^{13}$ almost half of retirees said they enjoyed life more than in the year before they retired. Those who enjoyed retirement less often reported health reasons as the cause.

9. Public Opinion Survey on Public Pension Scheme (1998), (Prime Minister's Cabinet Secretariat).

10. Finnish Old Age Barometer, 1994.

11. Jacobs and Shapiro (1998). Although support may have grown; inclusion of individual accounts is part of the mandate of the commission established in May 2001 to review Social Security.

12. The most interesting figure, however, is the very large number of people who indicated that they have not given any thought to their own retirement. It is, of course, younger people who have not thought about the retirement (only one third of people aged 15-24 had), but there still one-fifth of the people aged 55 and over responded in this way. Higher income people are most likely to look forward to retirement.

13. General Social Survey 1994. 
32. In the United States, analysis of many American polls suggests there is little support for raising the age of eligibility for social security. ${ }^{14}$ Indeed it is one of the least favoured reform options, even if it were to be introduced gradually. American survey data show that workers there want to retire early - at, or before 55, in many cases, and just under 60 years on average.

33. The ISSP survey found that the preference to spend more time in paid work declines with age and, in most countries, falls to under 10 per cent of people age 65 and over. By labour force status, the desire for more paid work is, unsurprisingly, highest among the unemployed and, in most countries, lowest among retired people. Retirees were most interested in paid work in Italy (22 per cent), the United States (11 per cent) and Germany (10 per cent). These results are found in the appended Table A3.

34. On the other hand, very different responses were given when people were asked what they would choose if they could decide on their own work situation at present. When asked in this manner, most retirees (and most people over the age of 65) said they would prefer to have paid work. The numbers of retirees who reported they would like to have no paid work at all was surprisingly small - ranging from lows in Italy (13 per cent) and Germany (17 per cent) to highs of only 38 per cent in the United Kingdom and 36 per cent in each of Canada and the United States. The data can be found in Table 6.

14. This discussion is based on Rix (1999). 
Table 6 Public views on own preferred labour force status, 1997

\begin{tabular}{|c|c|c|c|c|c|c|c|c|}
\hline \multirow[b]{4}{*}{ A full-time job } & \multicolumn{8}{|c|}{$\begin{array}{l}\text { Percentage of people picking the labour force status they would wish, in answer to the } \\
\text { question "Suppse you could decide on your work situation at present, which would you } \\
\text { choose?" }\end{array}$} \\
\hline & Canada & Germany & Italy & Japan & $\begin{array}{l}\text { Nether- } \\
\text { lands }\end{array}$ & Sweden & $\begin{array}{l}\text { United } \\
\text { Kingdom }\end{array}$ & $\begin{array}{l}\text { United } \\
\text { States }\end{array}$ \\
\hline & \multicolumn{8}{|c|}{ Percent of those age 50-64 } \\
\hline & 54.0 & 53.5 & 47.0 & 55.8 & 43.8 & 54.6 & 44.0 & 51.4 \\
\hline A part-time job & 28.5 & 35.7 & 39.3 & 24.9 & 27.1 & 40.1 & 37.4 & 33.2 \\
\hline $\begin{array}{l}\text { A job less than } 10 \\
\text { hours a week }\end{array}$ & 8.0 & 2.9 & 6.0 & 12.5 & 8.1 & 3.0 & 5.4 & 5.5 \\
\hline \multirow[t]{2}{*}{ No paid job } & 9.6 & 7.9 & 5.7 & 6.9 & 11.7 & 2.2 & 13.2 & 10.0 \\
\hline & \multicolumn{8}{|c|}{ Percent of those age $65+$} \\
\hline A full-time job & 20.5 & 57.0 & 36.5 & 39.2 & 32.3 & 45.0 & 31.5 & 24.9 \\
\hline A part-time job & 30.0 & 19.1 & 46.6 & 16.9 & 13.9 & 33.7 & 21.9 & 27.5 \\
\hline $\begin{array}{l}\text { A job less than } 10 \\
\text { hours a week }\end{array}$ & 12.7 & 5.3 & 2.7 & 14.8 & 3.5 & 9.0 & 8.3 & 14.8 \\
\hline \multirow[t]{2}{*}{ No paid job } & 36.8 & 18.5 & 10.4 & 29.1 & 31.3 & 12.4 & 38.3 & 32.8 \\
\hline & \multicolumn{8}{|c|}{ Percent of current retirees } \\
\hline A full-time job & 19.4 & 55.9 & 40.3 & 41.3 & 42.4 & 43.6 & 33.1 & 24.1 \\
\hline A part-time job & 29.8 & 24.1 & 38.1 & 16.3 & 12.8 & 32.2 & 21.4 & 24.1 \\
\hline $\begin{array}{l}\text { A job less than } 10 \\
\text { hours a week }\end{array}$ & 15.0 & 2.9 & 4.1 & 15.0 & 3.2 & 10.2 & 7.8 & 15.9 \\
\hline No paid job & 35.9 & 17.2 & 13.3 & 27.5 & 26.8 & 14.0 & 37.7 & 35.9 \\
\hline
\end{tabular}

Source: International Social Survey Programme 1997.

35. Similar results are found when employees are asked if they themselves intend to work after retirement. Many do, often for economic reasons. American polls ${ }^{15}$ taken 20 years ago indicated that just over half of pre-retirees would like to work after retirement, preferably in part-time or less demanding jobs. Today, over 70 per cent of workers indicated they expected to work after retirement. A 1998 American survey ${ }^{16}$ found the figure is even higher among the baby-boomer generation, those who are currently aged 36 to 54 . Over 80 per cent of them said that they plan to work after retirement. But in reality, the numbers of people who follow this route is small, at least up until now.

\footnotetext{
15. $\operatorname{Rix}(1999)$.

16. Baby-boomers Envision Their Retirement: An AARP Segmentation Analysis, (Roper Starch, 1999) mimeo.
} 
36. What accounts for these seemingly contradictory findings? Part of the explanation is that people were likely thinking of hypothetical, highly desirable jobs that were particularly suitable for them - ones that are in limited supply for most people. Another question would seem to bear this out. As shown in Table 7, only a relatively small number of retired people felt that it would be easy to find an acceptable job - likely a realistic answer given the labour force situation of many of the countries in 1997 when these questions were asked. The most optimistic were older Americans where a third thought it would at least be fairly easy to find a job and, indeed, the job market was stronger in the United States than in the other countries.

Table 7 Public perceptions on ease of finding a job, 1997

\begin{tabular}{|c|c|c|c|c|c|c|c|c|}
\hline & \multicolumn{8}{|c|}{$\begin{array}{c}\text { "If you were looking actively, how easy or difficult do you think } \\
\text { it would be for you to find an acceptable job" } \\
\text { Percent saying very and fairly easily }\end{array}$} \\
\hline & Canada & Germany & Italy & Japan & $\begin{array}{l}\text { Nether- } \\
\text { lands }\end{array}$ & Sweden & $\begin{array}{c}\text { United } \\
\text { Kingdom }\end{array}$ & $\begin{array}{l}\text { United } \\
\text { States }\end{array}$ \\
\hline $50-64$ & 25.8 & 6.0 & 10.0 & 5.8 & 12.6 & 17.5 & 15.7 & 44.7 \\
\hline $65+$ & 12.9 & 7.0 & 9.3 & 1.6 & 14.3 & 12.4 & 9.5 & 29.3 \\
\hline Retired & 23.9 & 7.8 & 9.0 & 2.5 & 16.1 & 10.8 & 9.7 & 32.7 \\
\hline
\end{tabular}

Source: International Social Survey Programme 1997.

\section{Views on working gradually}

37. Table 6 breaks out the preferences for desired paid work by full or part-time status. In fact, most retired people expressed a preference for full-time over part-time work, with work at a job of less than 10 hours being the least favoured. Canada is the main exception to this pattern with part-time work being preferred to full-time, while in the United States they are equally preferred. On the other hand, when workers are asked about their own wishes when they do reach retirement age, they have a stronger preference for part-time work.

38. In some countries, the acceptance of part-time work in retirement is quite recent. The 1992 Eurobarometer survey showed that, while a majority of people was in favour of a flexible retirement age, a significant minority favoured a fixed retirement age. In some EU countries (France, Spain, Luxembourg) there remains a strong feeling that pensioners should not be able to take on paid work, often related to views that this would be taking jobs away from younger people or that this is some form of double dipping. However, in the nine countries in this study, this is a common view only in Italy and there has been a small reduction in this view over the 1990s as is shown in Table 8. 
Table 8 Percent of people who think that retired people should be permitted to take paid employment, or that retired people should only work on voluntary basis, 1999

\begin{tabular}{|c|c|c|c|c|}
\hline & Paid employment & Voluntary work & $\begin{array}{l}\text { Both (spontaneous } \\
\text { response) }\end{array}$ & Don't know \\
\hline Finland & 53 & 28 & 16 & 3 \\
\hline Germany & 50 & 14 & 26 & 10 \\
\hline Italy & 25 & 42 & 19 & 14 \\
\hline Netherlands & 63 & 14 & 21 & 2 \\
\hline Sweden & 67 & 12 & 17 & 4 \\
\hline United Kingdom & 69 & 12 & 11 & 7 \\
\hline
\end{tabular}

Source : EUROBAROMETER.

\section{Will the growing number of older voters make a difference?}

39. The potential exists for a shift in the balance of political influence toward older people. There will be a larger number of older voters as the baby-boom generation retires. Older people vote in aboveaverage numbers. It used to be felt that as people withdrew from work, they withdrew from a more active life in other areas of society as well, including political involvement. In fact, there has been growth in more active political participation of older people ${ }^{17}$ in most of the European countries in our study - through lobbying (United Kingdom), in unions (Italy) in political parties (Germany), and even in forming older peoples' political parties (Netherlands). This kind of more active participation is well established in the United States; for example, the American Association of Retired People (AARP) is the largest lobby group in the world.

40. The growing number of older voters may, however, not shape future retirement income policy debates in any direct or large fashion. People's behaviours and views are affected by many factors in addition to age - work attachment, education, income, gender, and ethnic status. The AARP ${ }^{18}$, for example, points to the heterogeneity of older people in their organisation.

41. Older people are also pensioners and this provides a potentially strong common interest. However, the implications for future retirement income policy are not obvious. Much disquiet arises from fear of income insecurity for the elderly. But it is relatively easy to ensure stability in pensions once people are older - through grandfathering arrangements and advance notice. It is not clear that it is older people who are the most strongly opposed to change. The surveys discussed in this paper shows that, when looking at a range of pension-related issues, public opinion is not strongly or consistently related to age.

\section{Support for a new reform agenda}

42. There is a growing acceptance of a large role for private retirement savings but perhaps not yet for a greater role of earnings that is - enhancing income at older ages by working longer. There is no

\section{Walker and Naegele (1999)}

18. Rix (1999). 
opposition to working later in principle - people would like to work at older ages if the work were enjoyable. However, there may not be many jobs that meet older peoples' requirements for satisfying work - apart from a relatively small number of mainly well-educated, well-paid consultants, professionals and self-employed people. Also, most enjoy retirement. For all these reasons, there is often opposition to measures that would directly raise retirement ages. This opposition has not usually extended, however, to reforms that would provide incentives to accomplishing this through tighter links between benefits and contributions.

43. There are many differences in views across countries, but they do not appear to be systematically related to the actual retirement ages or pension arrangements in a country. In spite of some differences in views by age, there does not appear to be any growing cleavage along the lines of age on the issues discussed here.

44. The lack of a strong linkage between attitudes and actual retirement income arrangements, might be thought to reflect lack of public understanding of those retirement income arrangements. It is sometimes suggested that the complexity of the issues, together with a lack of understanding of how the system actually works, produces a polarised, often ideological, debate on retirement income policies. Indeed, surveys indicate that the details of pension designs tend to be poorly understood. However, there is a reasonably good understanding of the underlying principles (Jacobs and Shapiro, 1998) and many attitudes are realistic given the climate of the day. As noted, people may well like existing arrangements because, objectively, they coincide with their personal goals in most countries. They may lack confidence in their future because those arrangements are, in fact, under pressure. People may not favour working longer as a solution because, during this period, older workers were being laid-off.

45. While some of the survey data used in this paper are somewhat dated, the slow rate at which opinion has changed in the recent past suggests more up-to-date data would be unlikely to be significantly different. What trends there are suggest slightly growing support for a more diversified system of retirement income.

46. The expectation of the need for further reform is a feature of public dabate in most countries. The reaction to a particular proposal for change will, obviously, reflect national circumstances - the balance of winners and losers associated with that proposal. More generally, however, opinion data do not suggest any necessary problem in introducing greater diversity into retirement income provision along the lines that were outlined at the outset of this paper.

47. Working later is likely to be the topic of greatest public concern. People like to retire early, but their opposition to working later is not based on any fundamental principle. The main worry appears to centre on the existence of suitable jobs for older workers. This topic should, in consequence, be a main theme of reform agendas. Better empirical information, particularly on profound social changes that will result from the dramatic shift in balance between time spent in work and time spent in retirement, would certainly help constructive policy debates. 


\section{MAIN SOURCES}

Jacobs, Lawrence R., and Robert Y Shapiro (1998)

"Myths and Misunderstandings about Public Opinion Towards Social Security:

Knowledge, Support and Reformism."

〈http://www.polisci.umn.edu/faculty/ljacobs/myths.pdf>

Rix, Sara (1999)

"Social Security Reform: Rethinking retirement age policy - a look at raising Social Security's retirement age", Washington, AARP Public Policy Institute <http://research.aarp.org/econ/ib40_age_policy.html>

Smith, Tom W., (2001a)

"A cross-national Comparison on Attitudes towards Work by Age and Labor Force

Status" http://www.oecd.org. See 'ageing society' theme.

Smith, Tom W., (2001b)

"Public Support for Governmental Benefits for the Elderly Across Countries and Time" http://www.oecd.org. See 'ageing society' theme.

Walker, Alan (1999)

"Attitudes to Population Ageing in Europe: A comparison of the 1992 and 1999

Eurobarometer Surveys" < http://www.shef.ac.uk/uni/academic/R-

Z/socst/staff/staff_page_elements/a_walker/attitudes.pdf $>$

Walker A., and G. Naegele, Eds. (1999)

The Politics of Old Age in Europe, OU Press, Buckingham. 
Table A1 Views on role of government in providing a decent standard of living for the old by age, gender and labour force status, 1996

\begin{tabular}{|c|c|c|c|c|c|c|c|}
\hline & \multicolumn{7}{|c|}{$\begin{array}{l}\text { Percentage indicating that it should definitely be the government's responsibility to provide a } \\
\text { decent standard of living for the old }\end{array}$} \\
\hline & \multicolumn{3}{|r|}{ By age group } & & & \multicolumn{2}{|c|}{ By gender } \\
\hline & Under 30 & $30-39$ & $40-49$ & $50-64$ & $65+$ & Men & Women \\
\hline Canada & 38.4 & 47.2 & 51.0 & 54.0 & 62.7 & 42.0 & 55.8 \\
\hline Germany & 45.6 & 47.0 & 46.2 & 53.7 & 56.7 & 46.3 & 53.3 \\
\hline Italy & 69.3 & 77.9 & 73.4 & 78.1 & 80.4 & 73.5 & 77.5 \\
\hline Japan & 40.5 & 42.9 & 45.9 & 47.3 & 48.5 & 44.6 & 45.7 \\
\hline Sweden & 59.1 & 57.4 & 69.7 & 68.3 & 80.9 & 64.2 & 69.8 \\
\hline United Kingdom & 57.9 & 70.0 & 71.6 & 71.7 & 80.3 & 66.6 & 73.1 \\
\hline \multirow[t]{3}{*}{ United States } & 38.7 & 36.0 & 35.3 & 39.3 & 41.8 & 32.8 & 42.0 \\
\hline & \multicolumn{7}{|c|}{ By labour force status } \\
\hline & $\begin{array}{l}\text { Full-time } \\
\text { employees }\end{array}$ & $\begin{array}{l}\text { Part time } \\
\text { employees }\end{array}$ & Unemployed & Retired & $\begin{array}{l}\text { Keeping } \\
\text { house }\end{array}$ & Other & \\
\hline Canada & 45.4 & 46.4 & 35.9 & 61.7 & 45.6 & 52.9 & \\
\hline Germany & 47.2 & 48.0 & 57.3 & 57.0 & 53.0 & 40.3 & \\
\hline Italy & 74.8 & 74.1 & 73.2 & 81.7 & 75.4 & 70.4 & \\
\hline Japan & 43.5 & 47.4 & .. & 51.5 & 51.8 & 37.1 & \\
\hline Sweden & 60.1 & 65.6 & 74.1 & 81.6 &.. & 70.5 & \\
\hline United Kingdom & 63.7 & 68.5 & 92.4 & 78.2 & 71.3 & 76.2 & \\
\hline United States & 34.2 & 36.0 & .. & 42.1 & 46.5 & 51.6 & \\
\hline
\end{tabular}

.. Data not available.

Source: ISSP. 


\section{Table A2 Views on more public retirement spending}

by age, gender and labour force status, 1996

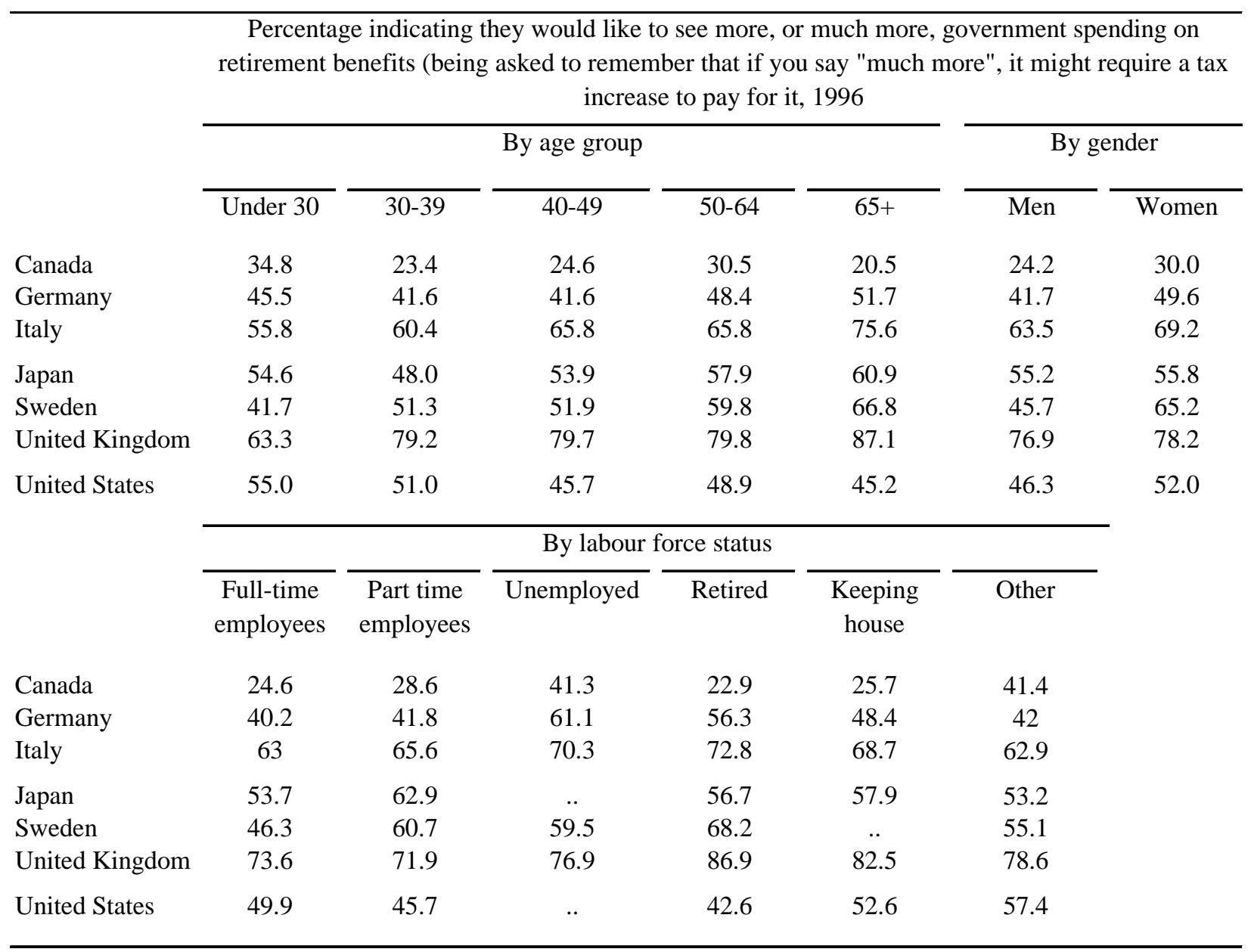

.. Data not available.

Source : ISSP. 
Table A3 Preferences for spending more time in a paid job, 1997

\begin{tabular}{|c|c|c|c|c|c|c|c|c|}
\hline \multirow[b]{4}{*}{ Under 30} & \multicolumn{8}{|c|}{$\begin{array}{l}\text { Percentage that picked "Wanting to spend more time in a paid job" in answer to the question } \\
\text { "Suppose you could change the way you spent your time", } 1997\end{array}$} \\
\hline & Canada & Germany & Italy & Japan & Netherlands & Sweden & $\begin{array}{c}\text { United } \\
\text { Kingdom }\end{array}$ & $\begin{array}{l}\text { United } \\
\text { States }\end{array}$ \\
\hline & \multicolumn{8}{|c|}{ By age } \\
\hline & 44.0 & 22.4 & 47.3 & 10.1 & 39.5 & 28.6 & 21.6 & 38.6 \\
\hline $30-39$ & 25.5 & 15.2 & 33.8 & 9.1 & 25.2 & 11.2 & 20.6 & 25.5 \\
\hline $40-49$ & 20.8 & 19.5 & 22.4 & 11.9 & 23.8 & 12.6 & 9.8 & 15.5 \\
\hline $50-64$ & 16.5 & 15.7 & 31.9 & 6.0 & 12.7 & 8.8 & 9.8 & 21.1 \\
\hline \multirow[t]{2}{*}{$65+$} & 5.5 & 9.3 & 21.4 & 2.6 & 2.6 & 8.3 & 3.0 & 11.1 \\
\hline & \multicolumn{8}{|c|}{ By labour force status } \\
\hline Full-time job & 11.0 & 8.0 & 15.0 & 5.1 & 9.8 & 3.6 & 3.0 & 18.9 \\
\hline Part-time job & 49.3 & 16.1 & 35.1 & 12.5 & 30.5 & 33.3 & 21.5 & 31.5 \\
\hline Unemployed & 50.7 & 46.6 & 91.3 &.. & 51.7 & 45.7 & 46.2 & 57.9 \\
\hline Retired & 8.2 & 10.4 & 22.2 & 2.7 & 2.9 & 8.7 & 3.6 & 11.4 \\
\hline Keeping house & 31.6 & 32.5 & 45.0 & 12.0 & 24.8 &.. & 24.8 & 30.0 \\
\hline
\end{tabular}

.. Data not available.

Source : ISSP 1997. 


\section{LABOUR MARKET AND SOCIAL POLICY OCCASIONAL PAPERS}

Most recent releases are:

No. 56 AN ASSESSMENT OF THE PERFORMANCE OF THE JAPANESE HEALTH CARE SYSTEM (2001) Hyoung-Sun Jeong and Jeremy Hurst

No. 54 PENSION REFORM IN THE SLOVAK REPUBLIC - BACKGROUND AND OPTIONS: CAN LESSONS BE DRAWN FROM OTHER TRANSITION COUNTRIES? (2001) Agnieszka Chlon, Marek Góra, Martina Lubyova, Lawrence H. Thompson

No. 53 TOWARDS MORE CHOICE IN SOCIAL PROTECTION? INDIVIDUAL CHOICE OF INSURER IN BASIC MANDATORY HEALTH INSURANCE IN SWITZERLAND (2001) Francesca Colombo

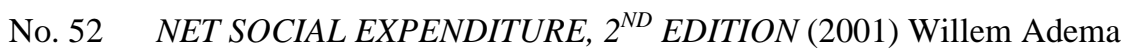

No. 51 GROWTH, INEQUALITY AND SOCIAL PROTECTION (2001) Roman Arjona, Maxime Ladaique and Mark Pearson

No. 50 KNOWLEDGE, WORK ORGANISATION AND ECONOMIC GROWTH (2001) Elena Arnal, Wooseok Ok and Raymond Torres

No. 49 AGE OF WITHDRAWAL FROM THE LABOUR FORCE IN OECD COUNTRIES (2001) Peter Scherer (forthcoming)

No. 48 FIRMS'CONTRIBUTION TO THE RECONCILIATION BETWEEN WORK AND FAMILY LIFE (2001) John M. Evans

No. 47 PERFORMANCE MEASUREMENT AND PERFORMANCE MANAGEMENT IN OECD HEALTH SYSTEMS (2001) Jeremy Hurst and Melissa Jee-Hughes

No. 46 EXPLORING THE EFFECTS OF HEALTH CARE ON MORTALITY ACROSS OECD COUNTRIES (2000) Zeynep Or

No. 45 TRENDS IN WORKING HOURS IN OECD COUNTRIES (2000) John M. Evans, Douglas C. Lippoldt and Pascal Marianna

No. 44 AN INVENTORY OF HEALTH AND DISABILLITY-RELATED SURVEYS IN OECD COUNTRIES (2000) Claire Gudex and Gaetan Lafortune

Recent available working papers can be found on the OECD internet site: http://www.oecd.org/.

Once at the OECD home page, you should go to the Education, Employment, Labour and Social Affairs Directorate under the OECD Directorates. Then, click on Documentation.

To receive a paper copy of any particular papers or to add your name to our mailing list, please send your name, organisation and full address to:

Labour Market and Social Policy Occasional Papers

Directorate for Education, Employment, Labour and Social Affairs

OECD, 2, rue André-Pascal, 75775 PARIS CEDEX 16, FRANCE

(write in capitals)

Name

Organisation

Address

Please send a copy of the following papers: numbers -- , -- , --.

Please add my name to the mailing list for future papers. 


\section{RECENT OECD PUBLICATIONS IN THIS FIELD INCLUDE:}

KNOWLEDGE AND SKILLS FOR LIFE: First Results from PISA 2000 (2001)

AGEING AND INCOME: Financial Resources and Retirement in 9 OECD Countries (2001)

HEALTH AT A GLANCE (2001)

SOCIETY AT A GLANCE: OECD Social Indicators (2001)

INNOVATIONS IN LABOUR MARKET POLICIES: The Australian Way (2001)

OECD EMPLOYMENT OUTLOOK June 2001 (published annually)

LABOUR MARKET POLICIES AND THE PUBLIC EMPLOYMENT SERVICE (Prague Conference) (2001)

TRENDS IN INTERNATIONAL MIGRATION: SOPEMI 2000 Edition (2001)

OECD HEALTH DATA (2001)

available in English, French, Spanish and German on CD-ROM (Windows 95, 98, 2000, NT or Me)

REFORMS FOR AN AGEING SOCIETY (2000)

PUSHING AHEAD WITH REFORM IN KOREA: Labour Market And Social Safety-Net Policies (2000)

A SYSTEM OF HEALTH ACCOUNTS (2000)

OECD ECONOMIC STUDIES No. 31, 2000/2 (Special issue on "Making Work Pay") (2000)

POLICIES TOWARDS FULL EMPLOYMENT (OECD Proceedings) (2000)

LABOUR MIGRATION AND THE RECENT FINANCIAL CRISIS IN ASIA:

(OECD Conference Proceedings) (2000)

OECD SOCIAL EXPENDITURE DATABASE, 1980-1997 (2000)

Second edition - Available in English and French on CD-ROM

A CARING WORLD - The New Social Policy Agenda (1999)

MAINTAINING PROSPERITY IN AN AGEING SOCIETY (1998)

THE BATTLE AGAINST EXCLUSION - Volume 3

Social Assistance in Canada and Switzerland (1999)

THE BATTLE AGAINST EXCLUSION - Volume 2

Social Assistance in Belgium, the Czech Republic, the Netherlands and Norway (1998)

THE BATTLE AGAINST EXCLUSION

Social Assistance in Australia, Finland, Sweden and the United Kingdom (1998)

BENEFIT SYSTEMS AND WORK INCENTIVES (1999) (Published bi-annually)

For a full list, consult the OECD On-Line Bookstore on: http://www.oecd.org or write for a free written catalogue to the following address:

OECD Publications Service

2, rue André-Pascal, 75775 PARIS CEDEX 16

or to the OECD Distributor in your country 